\title{
Complete-lactation milk and component yields following a short (35-d) or a conventional (60-d) dry period management strategy in commercial Holstein herds
}

\author{
D. E. Santschi, ${ }^{\star} \dagger^{1,2}$ D. M. Lefebvre, $\neq$ R. I. Cue,§ C. L. Girard,† and D. Pellerin* \\ *Département de sciences animales, Université Laval, Quebec, Canada, G1V 0A6 \\ †Agriculture and Agri-Food Canada, Dairy and Swine Research and Development Centre, Sherbrooke, Quebec, Canada, J1M 1 Z3 \\ $¥$ Valacta, Ste-Anne-de-Bellevue, Quebec, Canada, H9X 3R4 \\ §Department of Animal Science, McGill University, Ste-Anne-de-Bellevue, Quebec, Canada, H9X 3V9
}

\section{ABSTRACT}

A total of 850 cows distributed among 13 commercial Holstein herds were involved in this study to compare the effects of 2 different dry period (DP) management strategies on milk and component yields as well as body condition score (BCS) over complete lactations. Within each herd and every 2 mo, cows were assigned to a short (35 d dry; SDP) or conventional (60 d dry; CDP) DP management based on previous lactation 305-d milk yield, predicted calving interval, and parity: primiparous $(\mathrm{n}=414)$ and multiparous $(\mathrm{n}=436)$. Cows assigned to CDP were fed a far-off dry cow ration from dry-off until $21 \mathrm{~d}$ prepartum, and were then switched to a precalving ration. Cows assigned to SDP were fed the precalving ration throughout their DP. Rations were different across herds, but the late-lactation, precalving, and early lactation rations were identical for both treatment groups within each herd. Additional milk was obtained at the end of lactation from cows assigned to SDP due to the extended lactation. Average daily milk yield in the following lactation was not different between treatments for third- or greater-lactation cows, but was significantly decreased in second-lactation SDP cows. However, when expressed as energy-corrected milk, this difference was not significant. Although lower for primiparous than multiparous cows, body weight and BCS were not affected by DP management strategy. Milk production and BCS responses to treatments varied among herds. Results from the present study suggest that a short DP management strategy could be more appropriate for today's dairy cows, although not suitable for all cows or all herds.

Key words: short dry period, conventional dry period, production, dairy cow

\footnotetext{
Received July 5, 2010.

Accepted January 27, 2011.

${ }^{1}$ Current address: Valacta, Ste-Anne-de-Bellevue, Quebec, Canada,

${ }^{2}$ Corresponding author: dsantschi@valacta.com
} H9X 3R4.

\section{INTRODUCTION}

It is general practice in the dairy industry to allow cows a rest period between lactations. In the past, research results have suggested that maximum milk yield was obtained with a dry period (DP) managed for approximately $60 \mathrm{~d}$ (Schaeffer and Henderson, 1972; Funk et al., 1987; Makuza and McDaniel, 1996). These recommendations were often based on retrospective studies, which only accounted for production responses and did not consider the reasons for different DP lengths (e.g., early calving, twins, among others) or the management of those cows. The first planned studies where cows were actually assigned to fixed DP lengths compared conventional DP (60 d) with continuous milking (Swanson, 1965; Ackerman et al., 1967; Smith et al., 1967). These studies suggested that cows needed a period of rest to ensure complete regeneration of mammary cells and that continuous milking did not support maximum production. These observations are supported by findings from Capuco et al. (1997) who demonstrated an increased activity in mammary cells of cows that had $60 \mathrm{~d}$ dry compared with cows that were milked continuously.

In recent years, growing interest has developed toward shorter DP as a management strategy which could be more appropriate for today's high-producing dairy cows. Continuous milking still negatively affects production in the following lactation (Bachman and Schairer, 2003; Rastani et al., 2005; de Feu et al., 2009; Klusmeyer et al., 2009). However, short DP of 30 to 35 d yield additional milk at the end of lactation, which compensates for the small and often nonsignificant production loss in the following lactation (Gulay et al., 2003; Rastani et al., 2005; Watters et al., 2008; Klusmeyer et al., 2009). Nevertheless, these last studies and others (Pezeshki et al., 2007) suggest that the loss in the following lactation might be more important for primiparous cows.

In addition, some attention has been given to economically important parameters other than milk production 
when evaluating the optimal DP length. These factors include component yields, cow health and metabolism, as well as reproduction (Gümen et al., 2005; Rastani et al., 2005; Watters et al., 2009). Short DP management decreases the number and intensity of dietary changes during the DP, which improves energy balance in the following lactation and could have beneficial effects on reproduction (Gümen et al., 2005; Watters et al., 2008, 2009). Although the number of studies looking at these economical parameters is increasing, the number of cows involved is often too small to have sufficient statistical power to detect treatment differences. In addition, few non-retrospective studies compared the effects of different DP management strategies on complete lactations.

Most of the published planned experiments used several criteria for selecting cows involved in their study. To our knowledge, no recent research has been done looking at the effects of different DP management strategies on a large number of animals of various parities, production levels, calving intervals, and in commercial situations. The objective of the present study was, therefore, to compare the effects of a preplanned 35- or 60-d DP management strategy applied to a large number of cows from several different commercial dairy herds on milk and component yields as well as health and reproduction (reported elsewhere) to evaluate if a short DP management is suitable for today's dairy herds.

\section{MATERIALS AND METHODS}

All experimental procedures were approved by the Animal Care Committee from Université Laval, Quebec, Canada.

\section{Herds and Cows}

This study was conducted on 13 commercial dairy herds from Quebec, Canada. Herd sizes ranged from 37 to 175 cows (median $=68$ cows). All cows from each herd were involved in the experiment, except those with an estimated calving interval of $500 \mathrm{~d}$ or above $(\mathrm{n}=$ 112), leaving a total of 850 Holstein cows: 414 primiparous and 436 multiparous. The average herd production level before the experiment was 10,199 $\pm 325 \mathrm{~kg}$ per lactation, with an average lactation length of $336 \pm 4$ d. Herds were mainly housed in tie stall barns (11 out of 13). Five farms were feeding TMR, whereas the other 8 farms had individual concentrate feeding systems. Cows from one herd were milked 3 times daily; all others were milked twice. All herds were requested to have monthly individual cow milk recordings for production and composition as well as an existing transition cow management strategy (including dry-off and precalving rations) to join the study. In addition, herds with periodic herd health visits from a local veterinarian were prioritized due to the more accurate and precise health information available.

\section{Experimental Procedures}

The study lasted 2 yr: from January 2007 until December 2008. Within each herd and every 2 mo, cows in their sixth or seventh month of gestation were assigned to 1 of 2 DP management strategies based on parity (primiparous vs. multiparous), previous 305-d milk yield, and estimated calving interval. The DP management strategies compared were a conventional DP (CDP) and a short DP (SDP). In the CDP group, cows were dried $60 \mathrm{~d}$ before expected calving date. They received the late-lactation ration until being dried-off, then switched to a far-off dry cow ration until $21 \mathrm{~d}$ before expected calving, from when on they were fed the precalving ration. The cows on SDP were dried $35 \mathrm{~d}$ before the expected calving date. They were fed the late-lactation ration until dry-off and were directly switched to the precalving ration for the whole duration of their DP. If cows on SDP did not produce enough milk to be kept in lactation until 35 d before calving, the producer was allowed to dry them off and feed them the dry cow ration until $35 \mathrm{~d}$ before expected calving, when they were switched to the precalving ration. Cows from the CDP group that could not be milked until 60 $\mathrm{d}$ before calving were fed the dry-off ration for a longer period of time. All cows on SDP, therefore, received the precalving ration for $35 \mathrm{~d}$, whereas CDP cows were fed this ration for $21 \mathrm{~d}$. All cows were fed the early lactation ration after calving. Rations were specific to each herd (Table 1), but within each herd, late-lactation, precalving, and early lactation rations were the same for both treatment groups. Besides the ration change during the DP, producers were asked to feed and treat all cows as usual and to report all disease incidences, treatments, and breedings (reported elsewhere). Cows involved in the study were monitored until the end of the lactation following the assigned dry period. End of lactation was determined as either drying-off or culling. All cows participated in the study for 1 single dry period.

The method for drying-off was variable but key procedures were similar across herds: cows with low milk production (less than 10 to less than $15 \mathrm{~kg} / \mathrm{d}$, depending on herd) were dried abruptly, whereas highproducing cows were dried over several days, often with a single daily milking to decrease production. The duration of intermittent milking for high-producing cows varied from 2 to $5 \mathrm{~d}$, depending on herd. Together with this intermittent milking strategy, all producers 
Table 1. Average composition (range) of the rations offered in the herds according to stage of lactation ${ }^{1}$

\begin{tabular}{lcccc}
\hline Composition & $\begin{array}{c}\text { Late-lactation } \\
\text { ration }\end{array}$ & $\begin{array}{c}\text { Dry-off } \\
\text { ration }\end{array}$ & $\begin{array}{c}\text { Precalving } \\
\text { ration }\end{array}$ & $\begin{array}{c}\text { Early-lactation } \\
\text { ration }\end{array}$ \\
\hline $\mathrm{CP}, \% \mathrm{DM}$ & $16.5(15.6-17.9)$ & $11.2(8.3-13.2)$ & $14.1(13.0-16.0)$ & $17.3(15.8-18.9)$ \\
$\mathrm{RDP},{ }^{2} \% \mathrm{DM}$ & $10.8(9.1-12.0)$ & $7.3(4.4-10.5)$ & $9.6(7.7-11.0)$ & $11.0(9.1-11.8)$ \\
$\mathrm{RUP},{ }^{2} \% \mathrm{CP}$ & $34.3(29.5-41.8)$ & $33.9(24.0-47.2)$ & $34.8(29.0-44.7)$ & $36.4(30.7-42.2)$ \\
$\mathrm{NE}_{\mathrm{L}}{ }^{2} \mathrm{Mcal} / \mathrm{kg}$ & $1.58(1.52-1.67)$ & $1.35(1.20-1.56)$ & $1.52(1.39-1.60)$ & $1.62(1.53-1.73)$ \\
$\mathrm{ADF}, \% \mathrm{DM}$ & $22.7(19.9-27.2)$ & $33.2(28.3-35.4)$ & $26.9(22.8-31.4)$ & $20.8(18.3-24.3)$ \\
$\mathrm{NDF}, \% \mathrm{DM}$ & $36.2(31.6-41.8)$ & $56.0(49.7-62.7)$ & $45.4(40.9-51.4)$ & $33.0(26.3-39.1)$ \\
$\mathrm{NFC},{ }^{2} \% \mathrm{DM}$ & $38.5(34.4-47.5)$ & $25.6(23.1-31.3)$ & $32.8(27.9-38.3)$ & $39.3(34.1-41.8)$ \\
\hline
\end{tabular}

${ }^{1}$ Average and range for the 13 herds. Ration compositions were obtained from each herd's nutritionist, based on individual feed analyses done in the laboratory.

${ }^{2}$ Calculated according to NRC (2001).

lowered energy density of the ration by decreasing concentrates or TMR and increasing dry hay intake. None of the producers removed access to water to lower milk production before dry-off. Although they were asked to switch directly to the precalving ration for cows on SDP, producers were allowed to feed them a dry hayonly ration for 2 to $3 \mathrm{~d}$ to help drying-off. All producers used dry cow antibiotics at dry-off, and were provided with SNAP Beta-Lactam Tests (IDEXX Laboratories, Westbrook, ME) to detect residues in early lactation milk.

Herds were visited every other week throughout the project. The BCS was recorded at each visit [1 to 5 scale with quarter points, based on Wildman et al. (1982) and Ferguson et al. (1994)]. Scoring was done by the same individual in all herds and throughout the project. The BW of cows was evaluated by chest circumference (Heinrichs et al., 1992) at the first visit after calving.

Individual cow milk yield and composition (fat, protein, lactose, SCC, and urea) were measured monthly in each herd and test day and whole lactation records were obtained from Valacta (dairy production center of expertise, Quebec and Atlantic Provinces, Ste-Anne-deBellevue, Quebec, Canada). The ECM was calculated as follows: $\operatorname{ECM}(\mathrm{kg} / \mathrm{d})=12.55 \times$ fat $(\mathrm{kg} / \mathrm{d})+7.39$ $\times$ protein $(\mathrm{kg} / \mathrm{d})+0.2595 \times$ milk yield $(\mathrm{kg} / \mathrm{d})$. This equation was derived from the NRC (2001) equation for $\mathrm{NE}_{\mathrm{L}}$, considering a lactose concentration of $4.85 \%$ and the energy value of milk as $0.74 \mathrm{Mcal} / \mathrm{kg}$ of milk, as determined by Tyrrell and Reid (1965).

Feed samples were taken monthly on the farms, stored on ice during transportation and sent to Valacta Laboratories (Ste-Anne-de-Bellevue) for analysis. Ration compositions based on these analyses were obtained regularly from each herd's nutritionist.

\section{Statistical Analyses}

The LIFETEST procedure of SAS (version 9.2, SAS Institute, Cary, NC) was used to perform survival analysis of days dry. Shapes of lactation curves were estimated from the test-day records using the Wilmink curve parameters (Wilmink, 1987) and the MIXED procedure of SAS (SAS Institute, 1999). Fixed effects of the model were treatment, parity, DIM, expDIM (calculated as $e^{-0.05 \times \mathrm{DIM}}$ ), block, and herd, as well as the following interactions: treatment $\times$ parity, treatment $\times$ DIM, treatment $\times$ expDIM, parity $\times$ DIM, and parity $\times$ expDIM. Random regression effects (per cow) were intercept, DIM, and expDIM. The term parity referred to primiparous or multiparous at the time of dry-off, whereas block represented the 2-mo assignation period. The shape of the curve was defined by the intercept, DIM, and expDIM terms. Cows with fewer than 2 test-day records were not included. Curves for BCS were obtained with the same model. Daily ESTIMATE statements were produced for prediction of both lactation and BCS curves. The loss or gain of BCS over specific periods as well as total production over continuous days were also determined using the appropriate ESTIMATE statement in proc MIXED.

Calving interval, dry period length, previous 305-d and total lactation milk and component yields, as well as duration of lactation were analyzed with the same statistical model, except that intercept, DIM, expDIM, as well as all interactions with these terms were omitted because these were not continuous measures. Differences were declared significant at $P \leq 0.05$ and as a tendency at $0.05<P \leq 0.10$.

\section{RESULTS AND DISCUSSION}

Herds involved in the present study are similar to average Quebec dairy herds, although with higher production levels. In 2008, an average Quebec herd had 52 cows producing $8,501 \mathrm{~kg}$ of milk per lactation with an average calving interval of $427 \mathrm{~d}$ (Valacta, 2009). The number and details of cows lost during the study are reported elsewhere (Santschi et al., 2011). 


\section{Lactation Before the DP}

As mentioned previously, cows were assigned to treatments based on parity, previous 305-d milk yield and expected calving interval. Previous lactation 305-d milk yield was not different between DP groups $(P=0.25)$, but lower in primiparous than multiparous cows $(P<$ 0.001; Table 2). A significant treatment $\times$ parity interaction existed for actual calving interval for the lactation before the assigned DP $(P=0.05)$. No difference was found between treatment groups for primiparous cows, but multiparous CDP cows had a 10-d longer calving interval than did multiparous SDP cows $(P=$ 0.05). Gestation length was 279.4 and $279.1 \mathrm{~d}$, respectively, for multiparous CDP and SDP cows $(P=0.74)$. This variation in calving interval is, therefore, likely a result of assignation and is not caused by early or late calvings in either treatment group. Genetic indexes for milk, fat, and protein yields were not different among treatments $(P \geq 0.45$; data not shown $)$.

Actual days dry were $34.9 \pm 1.3$ and $60.1 \pm 1.5 \mathrm{~d}$ for primiparous, and $40.5 \pm 1.4$ and $70.9 \pm 1.4 \mathrm{~d}$ for multiparous, SDP and CDP cows, respectively. The survival curves for days dry in both treatment groups revealed some variation among actual DP lengths (Figure 1). This variation can be explained by the fact that this study was conducted in commercial dairy herds and was, therefore, held under several constraints that are not usually encountered in research herds. For example, calving interval, although balanced among the groups within each herd, was highly variable between herds (range: 379 to $437 \mathrm{~d}$; median $411 \mathrm{~d}$ ). In general, as calving interval increases, the end of lactation milk yield decreases. Producers were sometimes forced to dry some cows earlier, due to low production. In addition, some herds faced stall availability issues during higher calving seasons, as they had to milk more cows than usual due to the short DP; this also forced some early dry-offs. The incidence of twin calving was similar among treatments $(P=0.45)$, but twice as high

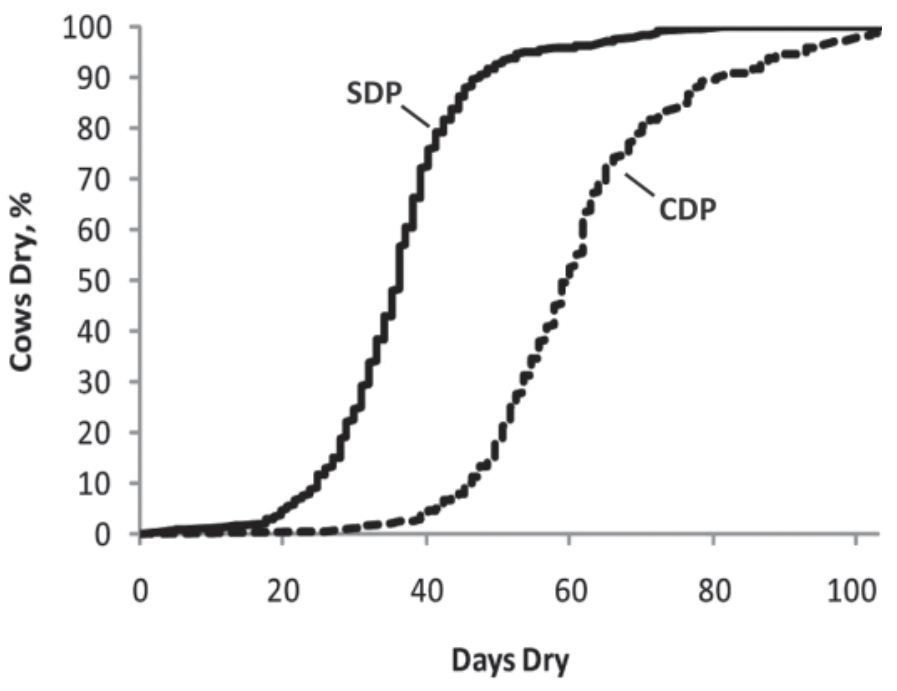

Figure 1. Survival curve of days dry for cows managed for short (35 d dry; SDP; continuous line) or conventional (60 d dry; CDP; dashed line) dry period.

in multiparous than primiparous cows (4.9 vs. $2.5 \%$, respectively; $P=0.001$ ). Data from all cows were kept for analysis.

Lactation before the DP was longer for SDP than CDP cows due to the extra DIM resulting from the shortened DP (Table 3). Accordingly, milk and component yields for the lactation before the studied DP were greater for cows on SDP than CDP in both parity groups $(P<0.001)$. Primiparous and multiparous cows on SDP were milked for an extra 25 and $30 \mathrm{~d}$, respectively (estimated from the DP length differences). Previous studies have reported that primiparous cows produce more milk than do multiparous cows during the last days before dry-off, probably as a result of better persistency (Annen et al., 2004; Pezeshki et al., 2007; Rastani et al., 2007). In our study, primiparous SDP cows produced $543.7 \pm 13.7 \mathrm{~kg}$ of milk, $24.01 \pm$ $0.57 \mathrm{~kg}$ of fat, and $20.39 \pm 0.45 \mathrm{~kg}$ of protein during these 25 d. Multiparous SDP cows produced $532.5 \pm$

Table 2. Number of cows, previous 305-d milk yield, and calving interval, as well as actual days dry according to parity and dry period (DP) management strategy

\begin{tabular}{|c|c|c|c|c|c|c|c|c|}
\hline \multirow[b]{2}{*}{ Item } & \multicolumn{2}{|c|}{ Parity 1} & \multicolumn{2}{|c|}{ Parity $2+$} & \multirow[b]{2}{*}{ SEM } & \multicolumn{3}{|c|}{$P$-value } \\
\hline & $\mathrm{CDP}^{1}$ & $\mathrm{SDP}^{2}$ & $\mathrm{CDP}^{1}$ & $\mathrm{SDP}^{2}$ & & Treatment & Parity & $\begin{array}{l}\text { Treatment } \\
\times \text { parity }\end{array}$ \\
\hline 305-d milk yield, $\mathrm{kg}$ & 8,580 & 8,630 & 10,495 & 10,709 & 152 & 0.25 & $<0.001$ & 0.41 \\
\hline Calving interval, $\mathrm{d}$ & 394.5 & 395.2 & $409.5^{\mathrm{b}}$ & $399.2^{\mathrm{a}}$ & 3.1 & 0.09 & 0.002 & 0.05 \\
\hline Actual days dry, $\mathrm{d}$ & 60.1 & 34.9 & 70.9 & 40.5 & 1.5 & $<0.001$ & $<0.001$ & 0.13 \\
\hline
\end{tabular}

${ }^{\mathrm{a}, \mathrm{b}}$ Means within the same row and parity group and with different superscripts differ; $P \leq 0.05$.

${ }^{1}$ Conventional DP, 60 d dry.

${ }^{2}$ Short DP, 35 d dry. 
Table 3. Total milk and component yields for the lactation before the assigned dry period (DP) according to parity and DP management strategy

\begin{tabular}{|c|c|c|c|c|c|c|c|c|}
\hline \multirow[b]{2}{*}{ Item } & \multicolumn{2}{|c|}{ Parity 1} & \multicolumn{2}{|c|}{ Parity $2+$} & \multirow[b]{2}{*}{ SEM } & \multicolumn{3}{|c|}{$P$-value } \\
\hline & $\mathrm{CDP}^{1}$ & $\mathrm{SDP}^{2}$ & $\mathrm{CDP}^{1}$ & $\mathrm{SDP}^{2}$ & & Treatment & Parity & $\begin{array}{l}\text { Treatment } \\
\times \text { parity }\end{array}$ \\
\hline Total lactation milk, $\mathrm{kg}$ & 9,847 & 10,414 & 11,782 & 12,366 & 221 & $<0.001$ & $<0.001$ & 0.95 \\
\hline Total lactation fat, $\mathrm{kg}$ & 369.9 & 394.4 & 446.7 & 467.9 & 9.2 & $<0.001$ & $<0.001$ & 0.76 \\
\hline Total lactation protein, $\mathrm{kg}$ & 325.3 & 347.8 & 388.1 & 407.5 & 7.1 & $<0.001$ & $<0.001$ & 0.72 \\
\hline
\end{tabular}

${ }^{1}$ Conventional DP, $60 \mathrm{~d}$ dry.

${ }^{2}$ Short DP, 35 d dry.

$17.0,23.63 \pm 0.70$, and $20.83 \pm 0.55 \mathrm{~kg}$ of extra milk, fat, and protein, respectively, during these $30 \mathrm{~d}$. This represents a daily average production level of $21.7 \mathrm{~kg}$ milk, at $4.4 \%$ fat and $3.7 \%$ protein for primiparous cows; and $17.8 \mathrm{~kg}$ milk, at $4.4 \%$ fat and $3.8 \%$ protein for multiparous cows. Additional end of lactation milk production obtained in our study is in the range of that reported in previous publications, which varied from 285 to $625 \mathrm{~kg}$ for 21 to $30 \mathrm{~d}$, although bST was used for some or all cows in most of these experiments (Gulay et al., 2003; Rastani et al., 2005; Pezeshki et al., 2007, 2008; Watters et al., 2008; Klusmeyer et al., 2009).

Component yields during the extended lactation are usually not measured and rarely reported. In our study, milk samples were taken monthly for all of the cows in each herd throughout the 24 mo of the project. We were, therefore, able to generate milk and component yield curves for the lactation before the DP. Extra fat and protein yields were estimated from the specific additional DIM for each parity group. Klusmeyer et al. (2009) reported average prepartum milk yield of 19.5 $\mathrm{kg} / \mathrm{d}$, with $4.06 \%$ fat and $3.56 \%$ true protein for multiparous cows with a $32 \mathrm{~d}$ DP. These values are similar to those from the present study, although cows from Klusmeyer et al. (2009) were supplemented with bST until 27 to $14 \mathrm{~d}$ before dry-off.

The SCS was not different among treatments $60 \mathrm{~d}$ before expected calving (test-day value: 2.78 and 2.99 \pm 0.15 for SDP and CDP, respectively; $P=0.44$ ).

\section{Lactation Following the DP}

Milk Production. Total lactation milk yields were $10,813 \pm 145$ and $10,091 \pm 125 \mathrm{~kg}$ for second-lactation cows (CDP and SDP, respectively) and 11,029 \pm 140 and $11,125 \pm 153 \mathrm{~kg}$ for third- and greater-lactation cows (CDP and SDP, respectively). It is important to note that these lactation yields are not compared on the same lactation length because although not significantly different $(P=0.29)$, lactation length following the DP was variable among groups (Table 4), especially for second-lactation cows. Average daily yield is, therefore, a more accurate value to allow proper comparison. The reason for the numerical difference observed for second-lactation cows is not known.

A tendency for a treatment $\times$ parity interaction was observed for average daily milk yield in the following lactation $(P=0.08$; Table 4 and Figure 2). Secondlactation SDP cows had lower average milk production than did cows on CDP $(P=0.01)$, but no difference was noted for third- or greater-lactation cows $(P=0.98$; Figure 2). These results are similar to those reported by other authors who observed lower milk production for second-lactation cows following a shortened DP, but no significant effect for older cows (Gulay et al., 2003; Annen et al., 2004; Pezeshki et al., 2007; Watters et al., 2008; Klusmeyer et al., 2009). In a study involving only multiparous cows, Pezeshki et al. (2008) reported lower daily milk yield during the first $210 \mathrm{~d}$ of lactation following a short DP (32.7 vs. $34.6 \mathrm{~kg} / \mathrm{d}$ for 28 - and 49-d DP, respectively), but no significant difference in total yield estimated for 305 d $(10,314$ vs. $10,831 \mathrm{~kg}$ for 28-and 49-d DP, respectively). On the other hand, Rastani et al. (2005) reported lower milk yields for both primiparous and multiparous cows when shortening the DP from 56 to $28 \mathrm{~d}$.

In our study, cows subjected to SDP before their second lactation produced $4.4 \%$ less milk daily than did CDP cows in the same parity group, over their whole lactation. In contrast, daily production loss for secondlactation cows reported by Rastani et al. (2005) averaged $9.3 \%$ over the first 70 DIM $(39.8$ vs. $36.1 \mathrm{~kg} / \mathrm{d}$ for cows with 60 and $28 \mathrm{~d}$ dry, respectively), whereas it was approximately $7.8 \%$ over the first 100 DIM for Watters et al. (2008) who compared 55 and 34 d dry (42.3 vs. $39.0 \mathrm{~kg} / \mathrm{d}$ for 55 and $34 \mathrm{~d}$ dry, respectively). Pezeshki et al. (2007) suggested losses up to $11.4 \%$. Estimating average daily production of second-lactation cows over the first 100 DIM in our study $(38.8$ and $37.4 \mathrm{~kg} / \mathrm{d}$, for CDP and SDP, respectively) results in an approximate 
Table 4. Body weight, lactation length, and postpartum milk and component yields according to parity and dry period (DP) management strategy

\begin{tabular}{|c|c|c|c|c|c|c|c|c|}
\hline \multirow[b]{2}{*}{ Item } & \multicolumn{2}{|c|}{ Parity 2} & \multicolumn{2}{|c|}{ Parity $3+$} & \multirow[b]{2}{*}{ SEM } & \multicolumn{3}{|c|}{$P$-value } \\
\hline & $\mathrm{CDP}^{1}$ & $\mathrm{SDP}^{2}$ & $\mathrm{CDP}^{1}$ & $\mathrm{SDP}^{2}$ & & Treatment & Parity & $\begin{array}{c}\text { Treatment } \\
\times \text { parity }\end{array}$ \\
\hline $\begin{array}{l}\text { Lactation length, d } \\
\text { Production }\end{array}$ & 347.2 & 334.8 & 333.8 & 332.6 & 7.1 & 0.29 & 0.27 & 0.38 \\
\hline Milk, kg/d & $31.5^{\mathrm{b}}$ & $30.1^{\mathrm{a}}$ & 32.7 & 32.7 & 0.4 & 0.15 & $<0.001$ & 0.08 \\
\hline Fat, $\mathrm{kg} / \mathrm{d}$ & 1.20 & 1.17 & 1.26 & 1.27 & 0.02 & 0.97 & $<0.001$ & 0.18 \\
\hline Protein, \% & $3.31^{\mathrm{a}}$ & $3.40^{\mathrm{b}}$ & 3.31 & 3.33 & 0.02 & $<0.001$ & $<0.001$ & 0.009 \\
\hline Protein, kg/d & 1.02 & 1.01 & 1.06 & 1.07 & 0.01 & 0.95 & $<0.001$ & 0.53 \\
\hline Lactose, \% & 4.56 & 4.54 & 4.45 & 4.47 & 0.01 & 0.42 & 0.09 & 0.04 \\
\hline Lactose, $\mathrm{kg} / \mathrm{d}$ & $1.50^{\mathrm{b}}$ & $1.42^{\mathrm{a}}$ & 1.53 & 1.54 & 0.02 & 0.23 & $<0.001$ & 0.01 \\
\hline MUN, mg of $\mathrm{N} / \mathrm{dL}$ & $11.6^{\mathrm{b}}$ & $11.2^{\mathrm{a}}$ & 11.2 & 11.3 & 0.1 & 0.16 & 0.86 & 0.05 \\
\hline SCS & 2.41 & 2.56 & $3.21^{\mathrm{b}}$ & $2.98^{\mathrm{a}}$ & 0.12 & 0.23 & 0.008 & 0.07 \\
\hline
\end{tabular}

\footnotetext{
${ }^{a, b}$ Means within the same row and parity group and with different superscripts differ; $P \leq 0.05$.

${ }^{1}$ Conventional DP, $60 \mathrm{~d}$ dry.

${ }^{2}$ Short DP, 35 d dry.

${ }^{3}$ Measured at the first visit after calving.
}

loss of $3.6 \%$, which is less than half the values estimated from the literature. Average age at first calving was 26.3 mo for primiparous cows involved in the present study. It could be hypothesized that heifers calving at an older age are more mature at the end of their first lactation and could, therefore, be better candidates for SDP compared with heifers that calved at a younger age. Other published papers did not provide information on age at first calving.

Our results confirm that shortening the DP of primiparous cows decreases daily milk production in the following lactation, but to a lesser extent than reported in previously published studies. More importantly, expressed as ECM, average daily production was not different among treatments $(P=0.70)$, although lower for second-lactation cows than older cows $(P<0.001$; Table 4 and Figure 2). Similarly, Rastani et al. (2005) observed no difference in daily SCM when comparing 28- to 56-d DP, even though these authors did not report separate results for the 41 primiparous and 24 multiparous cows involved in their study. In contrast to our results, Watters et al. (2008) reported significantly lower SCM yield for primiparous cows assigned to a shortened DP over the first 100 DIM, but no treatment differences for third- or greater-lactation cows, which is similar to our data.

Milk Composition. Fat percentage did not differ among parity groups or treatments $(P \geq 0.14$; Table 4 and Figure 3). Rastani et al. (2005) found a significant increase in fat concentration following a shorter DP, as fat percentages were 3.86 and $4.08 \%$ in early lacta- tion following a 56 or $28-\mathrm{d}$ DP, respectively. On the other hand, and similar to our results, several authors have reported that fat content was not affected by DP length (Gulay et al., 2003; Annen et al., 2004; Watters et al., 2008; Klusmeyer et al., 2009). The average daily milk fat yield was lower for second-lactation cows than for older cows $(P<0.001)$ but was not affected by DP management strategy $(P=0.97$; Table 4$)$. This is in agreement with the literature, which suggests little (Pezeshki et al., 2008) or no (Rastani et al., 2005; Pezeshki et al., 2007; Watters et al., 2008) decrease in fat yield following a short DP.

A significant treatment $\times$ parity interaction was observed for protein percentage. In our study, protein content was increased in second-lactation SDP cows compared with CDP cows $(P<0.001$; Figure 3$)$. This difference was highest in early lactation and decreased over time. No treatment effect existed for older cows $(P=0.55$; Table 4$)$. Watters et al. (2008) reported a significant treatment effect, but no treatment $\times$ parity effect; protein percentage was increased in both second lactation (2.71 vs. $2.88 \%$ for 56 and $34 \mathrm{~d}$ dry, respectively) and third- or greater-lactation cows (2.64 vs. $2.77 \%$ for 56 and $34 \mathrm{~d}$ dry, respectively) in their study. Similarly, Rastani et al. (2005) reported greater protein percentage following a shortened DP (2.83 vs. $2.97 \%$ for 56 and 28 d dry, respectively), whereas Annen et al. (2004) found increased milk true protein content in milk of second-lactation cows following a shorter DP, but no effect in milk of older cows. The average daily protein production was lower for second-lactation cows 

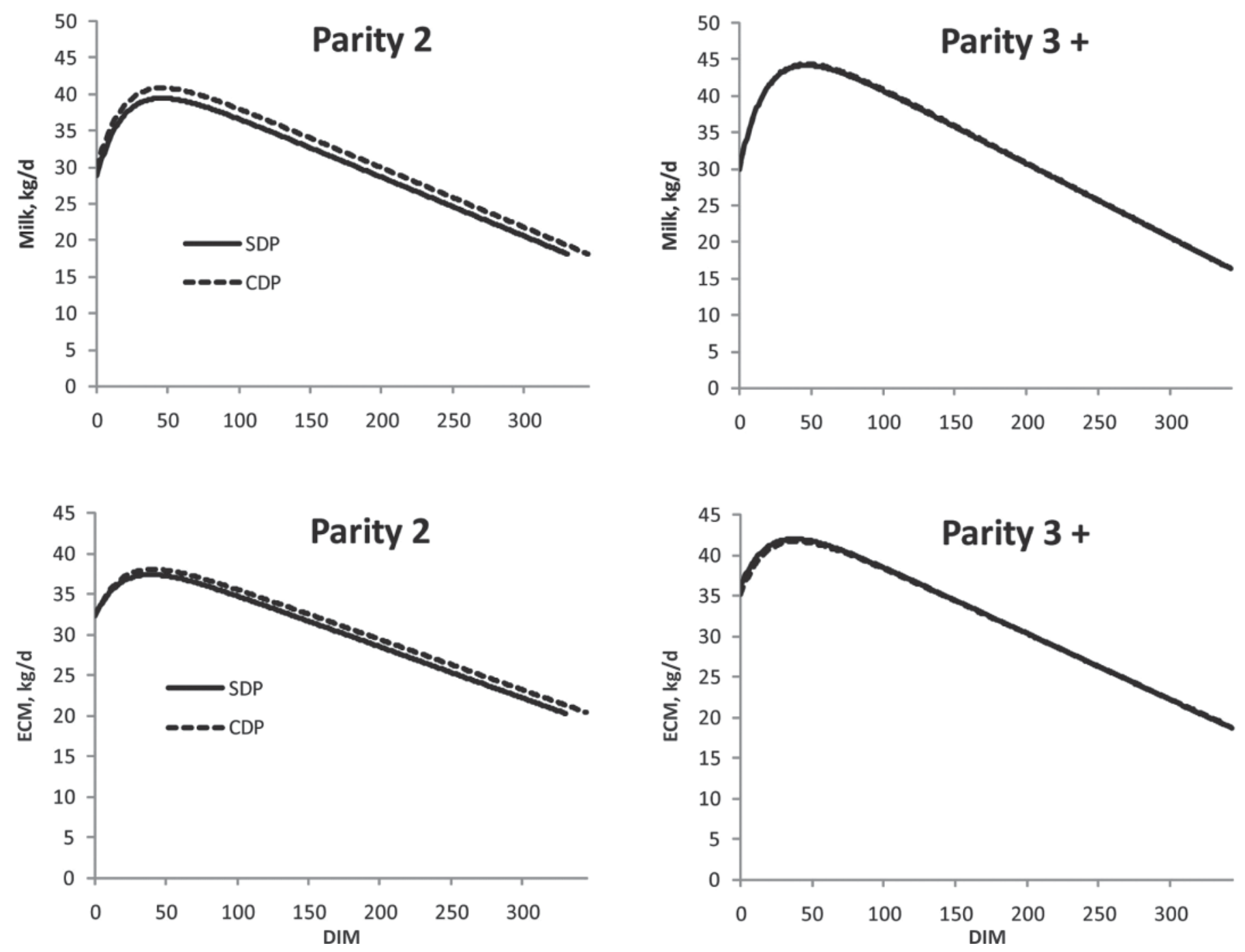

Figure 2. Milk and ECM yields for the subsequent lactation according to parity and dry period (DP) management strategy. SDP = short $\mathrm{DP}, 35 \mathrm{~d}$ dry, continuous line; CDP = conventional DP, $60 \mathrm{~d}$ dry, dashed line. The average standard error was $0.51 \mathrm{~kg} / \mathrm{d}$ for milk and $0.48 \mathrm{~kg} / \mathrm{d}$ for ECM. ECM $(\mathrm{kg} / \mathrm{d})=12.55 \times$ fat $(\mathrm{kg} / \mathrm{d})+7.39 \times$ protein $(\mathrm{kg} / \mathrm{d})+0.2595 \times$ milk yield $(\mathrm{kg} / \mathrm{d})$.

compared with older cows $(P<0.001)$, but was not affected by treatment $(P=0.95$; Table 4$)$. On the other hand, Pezeshki et al. (2007) reported decreased daily protein yield following a short DP. Protein concentrations and yields reported by these authors are lower than observed in the present study, probably because total protein was measured in the present study, whereas true protein is mostly reported elsewhere.

Effects of short DP on lactose yield and percentage are rarely reported in the literature. In our study, a significant treatment $\times$ parity effect was found for average daily lactose yield and percentage $(P \leq 0.04$; Table 4$)$. However, differences in lactose concentrations were limited between CDP and SDP within each parity group. Separate analysis by parity group did not reveal signifi- cant treatment effects $(P \geq 0.11)$. In terms of lactose yield, separate analysis for each parity group revealed that second-lactation CDP cows produced more lactose than did SDP cows $(P=0.004)$ but this effect was not significant for third- or greater-lactation cows $(P=$ 0.62 ). These observations on lactose are consistent with the effects of treatments on milk yield. Similarly, Rastani et al. (2005) obtained lower average lactose yields $(0.21 \mathrm{~kg} / \mathrm{d}$ less $)$ for cows managed with a $28-\mathrm{d}$ DP in a group of primiparous and multiparous cows.

A significant treatment $\times$ parity interaction also was observed for MUN concentration $(P=0.05$; Table 4$)$. Second-lactation SDP cows had lower MUN concentrations than did CDP cows $(P=0.02)$, whereas no difference was noted among third- or greater-lactation cows 

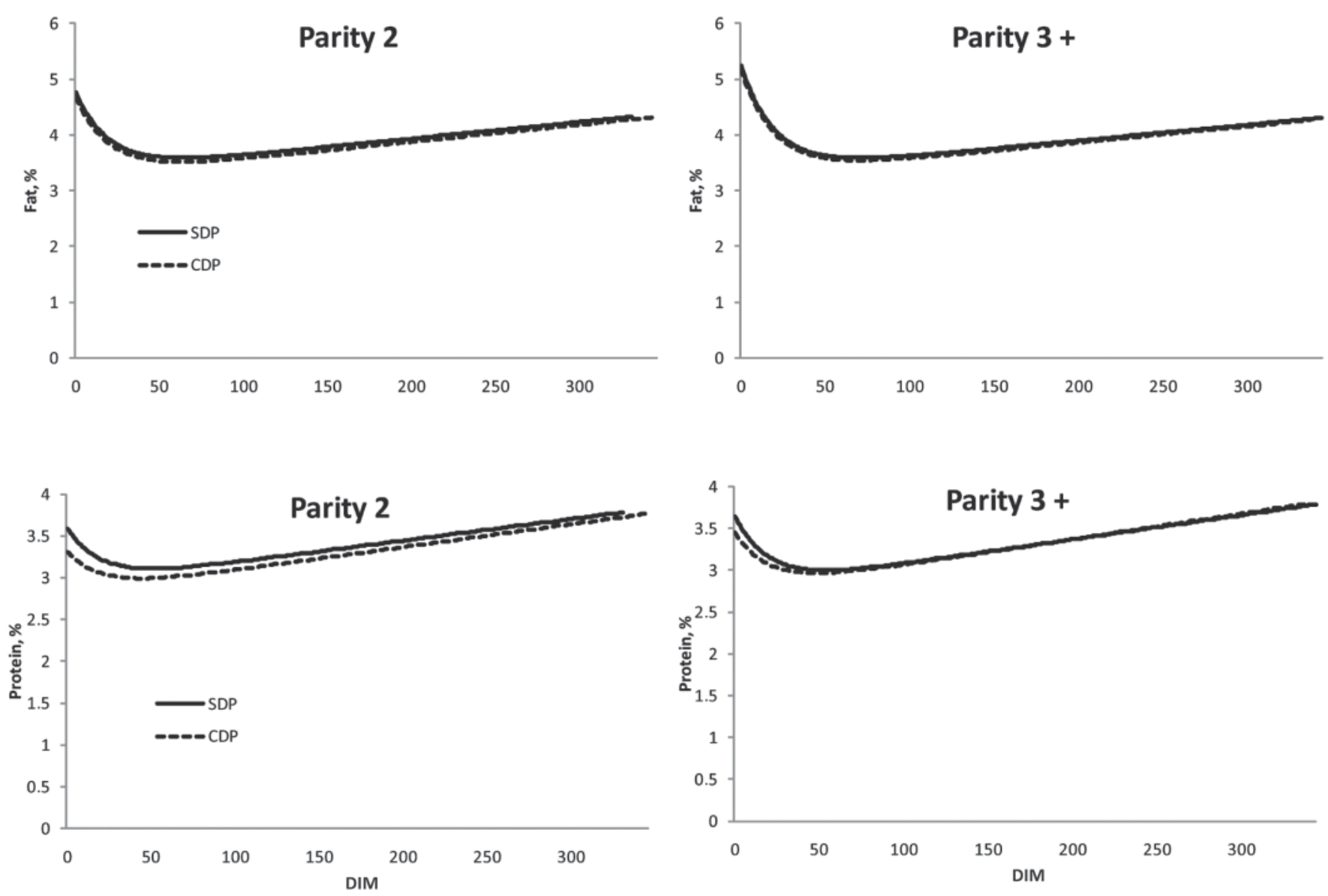

Figure 3. Fat and protein concentrations for the subsequent lactation according to parity and dry period (DP) management strategy. SDP $=$ short DP, $35 \mathrm{~d}$ dry, continuous line; CDP = conventional DP, $60 \mathrm{~d}$ dry, dashed line. The average standard error was $0.04 \%$ for fat content and $0.02 \%$ for protein content.

$(P=0.67)$. Although SDP cows are still within the acceptable MUN concentration range, the reason for this decrease is unknown. To our knowledge, no previous report exists of effects of DP management strategy on MUN concentrations.

Somatic cell score tended to have a treatment $\times$ parity interaction over the lactation following the assigned DP $(P=0.08$; Table 4$)$. The DP management strategy used had no effect on SCS for second-lactation cows $(P$ $=0.54)$. However, third-lactation cows on SDP tended to have a lower score than CDP cows in the subsequent lactation $(P=0.09)$. Rastani et al. (2005) also reported a tendency for lower SCS when the DP was decreased from 56 to $28 \mathrm{~d}$, whereas others reported no effect of DP on SCS (Gulay et al., 2003; Annen et al., 2004; Watters et al., 2008).

$\boldsymbol{B} \boldsymbol{W}$ and $\boldsymbol{B C S}$. Body weight, evaluated by chest circumference at the first visit after calving, was not different between treatments but was lower for cows in their second lactation than cows in their third or greater lactation $(657.8$ vs. $708.2 \pm 3.7 \mathrm{~kg}$, respectively; $P<0.001)$.

The average BCS $60 \mathrm{~d}$ before expected calving was not different between treatment groups $(P=0.23)$, and was similar for primiparous and multiparous cows (3.13 vs. $3.12 \pm 0.03$ for primiparous and multiparous cows, respectively; $P=0.97)$. By $35 \mathrm{~d}$ before expected calving, all cows had gained, on average, 0.05 points of BCS, no matter the parity or DP management strategy $(P \geq 0.87)$. At calving, BCS was 2.95 and $3.15 \pm$ $0.04(P<0.001)$, respectively, for second- vs. third- or greater-lactation cows. This value was not affected by DP management strategy $(P=0.68)$, suggesting that milking cows for an extra 25 to $30 \mathrm{~d}$ at the end of lactation and feeding them a precalving ration for 35 d instead of $21 \mathrm{~d}$ did not affect body reserves in our study.

In the following lactation, the lowest BCS point was around 50 DIM for all parity and treatment groups. On average, cows in their second lactation lost $0.40 \pm$ 
$\mathbf{A}$
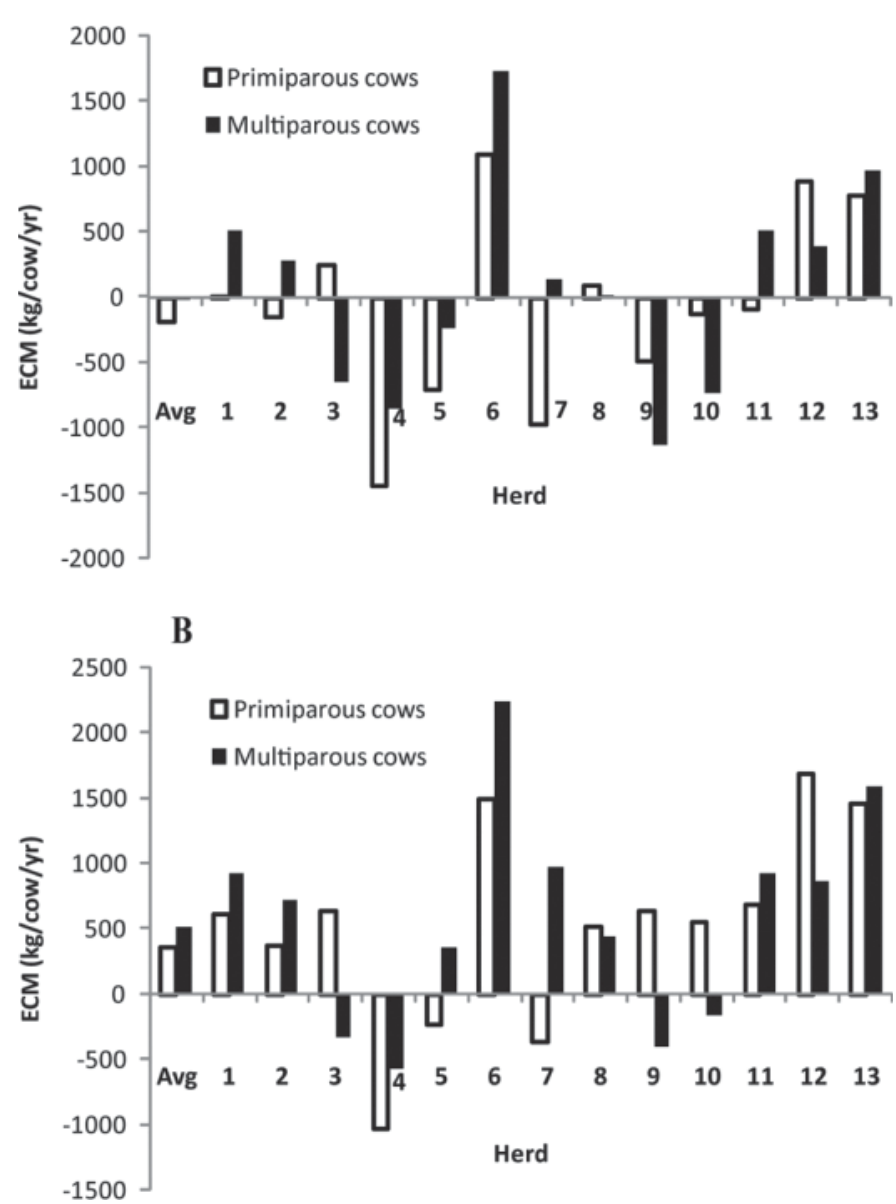

Figure 4. Variation in production response on average (Avg) and among the 13 herds involved in the study for primiparous (white bars) and multiparous cows (black bars). Values are presented as annual yield of ECM per cow. Bars represent the difference between short (35d) and conventional (60-d) dry period management strategies for the subsequent lactation only (A) or accounting for the extra milk production at the end of lactation (B). The respective number of primiparous and multiparous cows involved in the study per herd was $1=42$ and $41 ; 2=25$ and $29 ; 3=39$ and $45 ; 4=37$ and $39 ; 5=77$ and $82 ; 6=$ 26 and $25 ; 7=33$ and $30 ; 8=15$ and $23 ; 9=27$ and $27 ; 10=24$ and $26 ; 11=24$ and $29 ; 12=14$ and $20 ; 13=34$ and 17 .

0.04 points, whereas older cows lost $0.73 \pm 0.03$ points $(P<0.001)$. Again, this loss was not affected by DP management strategy $(P=0.34)$.

It has previously been suggested that shorter DP improve BCS in the following lactation by minimizing BCS loss in early lactation and, therefore, result in cows managed for short DP having higher postpartum BCS. Gulay et al. (2003) and Rastani et al. (2005) reported greater postpartum BCS loss for cows managed with a traditional DP compared with cows that received a shorter DP. Pezeshki et al. (2007) noted higher BCS for cows on SDP by wk 15 postpartum. Similarly, Watters et al. (2008) reported higher postpartum BCS for cows assigned to a SDP (3.01 vs. 3.07 for conventional and short DP, respectively) but specified that the average difference was less than one-tenth of a point. The reason that our results do not confirm the literature might be due to several factors, including feeding and management of cows. However, in the present experiment, BCS results are consistent with milk production response: the fact that no difference existed in ECM yields between treatments within both parity groups for the following lactation explains the absence of differences in BCS.

\section{Variation Among Herds}

The main objective of the present study was to evaluate the effects of SDP management on a large number of Holstein cows. To do so, and due to the actual situation in the province of Quebec, where the average herd size is 52 cows (Valacta, 2009), several herds had to be involved to reach the target number of animals. To our knowledge, this is the first study using a planned design to look at the effects of different DP management strategies over complete lactations and in several different commercial herds. Analyses of effects of SDP management revealed considerable variation among herds, both for BCS changes and production responses.

Due to variable numbers of animals in each herd, production values are reported as differences in annual yields of ECM on a cow basis. Differences were obtained as SDP - CDP. Figure 4 illustrates the production responses for the lactation following the studied DP only (A) and when accounting for the extra milk production obtained at the end of the previous lactation due to the shorter DP (B). Differences between the 2 graphs illustrate the amounts of extra milk and components obtained at the end of lactation.

Our results suggest that a shorter DP is generally beneficial as a management strategy but might not be appropriate in all management schemes represented by herds involved in our study. Specific conditions altering the responses to DP management strategy need to be investigated.

\section{CONCLUSIONS}

Our results mostly agree with the recent literature and indicate that decreasing the DP from 60 to $35 \mathrm{~d}$ in commercial herds decreased total lactation milk yield in second-lactation cows. However, observations from the present study demonstrate that the DP management strategy has no effect on ECM yield no matter the parity. Extra milk could be obtained from the extended lactation without negative effects on production during the following lactation. No effect was noted on BCS 
in our study. However, according to production results from the different herds, it appears that a 35-d DP management strategy might not be the ideal solution for all cows or for all herds. Further analyses are needed to fully understand the reasons for the between-herd variation.

\section{ACKNOWLEDGMENTS}

The authors acknowledge the invaluable contribution of the producers, veterinarians, and nutritionists involved in this study for their participation and collaboration. This project was financed by the Action concertée Novalait-FQRNT-MAPAQ-AAC (Quebec, Quebec, Canada).

\section{REFERENCES}

Ackerman, R. A., R. O. Thomas, and D. F. Butcher. 1967. Effects of length of dry period on production. J. Dairy Sci. 50:976-977. (Abstr.)

Annen, E. L., R. J. Collier, M. A. McGuire, J. L. Vicini, J. M. Ballam, and M. J. Lormore. 2004. Effect of modified dry period lengths and bovine somatotropin on yield and composition of milk from dairy cows. J. Dairy Sci. 87:3746-3761.

Bachman, K. C., and M. L. Schairer. 2003. Invited review: Bovine studies on optimal lengths of dry periods. J. Dairy Sci. 86:30273037.

Capuco, A. V., R. M. Akers, and J. J. Smith. 1997. Mammary growth in Holstein cows during the dry period: Quantification of nucleic acids and histology. J. Dairy Sci. 80:477-487.

de Feu, M. A., A. C. Evans, P. Lonergan, and S. T. Butler. 2009. The effect of dry period duration and dietary energy density on milk production, bioenergetic status, and postpartum ovarian function in Holstein-Friesian dairy cows. J. Dairy Sci. 92:6011-6022.

Ferguson, J. D., D. T. Galligan, and N. Thomsen. 1994. Principal descriptors of body condition score in Holstein cows. J. Dairy Sci. 77:2695-2703.

Funk, D. A., A. E. Freeman, and P. J. Berger. 1987. Effects of previous days open, previous days dry, and present days open on lactation vield. J. Dairy Sci. 70:2366-2373.

Gulay, M. S., M. J. Hayen, K. C. Bachman, T. Belloso, M. Liboni, and H. H. Head. 2003. Milk production and feed intake of Holstein cows given short (30-d) or normal (60-d) dry periods. J. Dairy Sci. 86:2030-2038.

Gümen, A., R. R. Rastani, R. R. Grummer, and M. C. Wiltbank. 2005. Reduced dry periods and varying prepartum diets alter postpartum ovulation and reproductive measures. J. Dairy Sci. 88:2401-2411.

Heinrichs, A. J., G. W. Rogers, and J. B. Cooper. 1992. Predicting body weight and wither height in Holstein heifers using body measurements. J. Dairy Sci. 75:3576-3581.

Klusmeyer, T. H., A. C. Fitzgerald, A. C. Fabellar, J. M. Ballam, R. A. Cady, and J. L. Vicini. 2009. Effect of recombinant bovine so- matotropin and a shortened or no dry period on the performance of lactating dairy cows. J. Dairy Sci. 92:5503-5511.

Makuza, S. M., and B. T. McDaniel. 1996. Effects of days dry, previous days open, and current days open on milk yields in cows in Zimbabwe and North Carolina. J. Dairy Sci. 79:702-709.

NRC. 2001. Nutrient Requirements of Dairy Cattle. 7th ed. National Academy Press, Washington, DC.

Pezeshki, A., J. Mehrzad, G. R. Ghorbani, B. De Spiegeleer, R. J. Collier, and C. Burvenich. 2008. The effect of dry period length reduction to 28 days in the performance of multiparous dairy cows in the subsequent lactation. Can. J. Anim. Sci. 88:449-456.

Pezeshki, A., J. Mehrzad, G. R. Ghorbani, H. R. Rahmani, R. J. Collier, and C. Burvenich. 2007. Effects of short dry periods on performance and metabolic status in Holstein dairy cows. J. Dairy Sci. 90:5531-5541.

Rastani, R. R., N. S. del Rio, T. F. Gressley, G. E. Dahl, and R. R. Grummer. 2007. Effects of increasing milking frequency during the last 28 days of gestation on milk production, dry matter intake, and energy balance in dairy cows. J. Dairy Sci. 90:1729-1739.

Rastani, R. R., R. R. Grummer, S. J. Bertics, A. Gümen, M. C. Wiltbank, D. G. Mashek, and M. C. Schwab. 2005. Reducing dry period length to simplify feeding transition cows: Milk production, energy balance, and metabolic profiles. J. Dairy Sci. 88:1004-1014.

Santschi, D. E., D. M. Lefebvre, R. I. Cue, C. L. Girard, and D. Pellerin. 2011. Incidence of metabolic disorders and reproductive performance following a short $(35 \mathrm{~d})$ or 16 conventional $(60 \mathrm{~d})$ dry period management in commercial Holstein herds. J. Dairy Sci. doi:10.3168/jds.2010-3595

SAS Institute. 1999. User's Guide: Statistics. Version 8. SAS Institute, Cary, NC.

Schaeffer, L. R., and C. R. Henderson. 1972. Effects of days dry and days open on Holstein milk production. J. Dairy Sci. 55:107112

Smith, A., J. V. Wheelock, and F. H. Dodd. 1967. The effect of milking throughout pregnancy on milk secretion in the succeeding lactation. J. Dairy Res. 34:145-150.

Swanson, E. W. 1965. Comparing continuous milking with sixty-day dry periods in successive lactations. J. Dairy Sci. 48:1205-1209.

Tyrrell, H. F., and J. T. Reid. 1965. Prediction of the energy value of cow's milk. J. Dairy Sci. 48:1215-1223.

Valacta. 2009. Évolution de la production laitière québécoise 2008. Pages 33-62 in Le Producteur de Lait Québécois. Numéro spécial.

Watters, R. D., J. N. Guenther, A. E. Brickner, R. R. Rastani, P. M. Crump, P. W. Clark, and R. R. Grummer. 2008. Effects of dry period length on milk production and health of dairy cattle. J. Dairy Sci. 91:2595-2603.

Watters, R. D., M. C. Wiltbank, J. N. Guenther, A. E. Brickner, R. R. Rastani, P. M. Fricke, and R. R. Grummer. 2009. Effect of dry period length on reproduction during the subsequent lactation. J. Dairy Sci. 92:3081-3090.

Wildman, E. E., G. M. Jones, P. E. Wagner, and R. L. Boman. 1982. A dairy cow body condition scoring system and its relationship to selected production characteristics. J. Dairy Sci. 65:495-501.

Wilmink, J. B. M. 1987. Adjustment of test-day milk, fat and protein yield for age, season and stage of lactation. Livest. Prod. Sci. $16: 335-348$. 